\title{
Media Belajar Sejarah Di Sekolah Menengah Pertama Kelas IX Semester Ganjil
}

\author{
Abdul Rahman ${ }^{1}$, Destiarini ${ }^{2}$ \\ ${ }^{1}$ Dosen Tetap Prodi Informatika Fakultas Teknik Dan Komputer Universitas Baturaja \\ Jl. Ratu Penghulu No.2301 Karang Sari Telepon (0735) 326122 Fax. 321822; \\ e-mail: abdulrahman@ft.unbara.ac.id \\ ${ }^{2}$ Dosen Tetap Prodi Informatika Fakultas Teknik Dan Komputer Universitas Baturaja \\ J1. Ratu Penghulu No.2301 Karang Sari Telepon (0735) 326122 Fax. 321822; \\ e-mail: destiarini@ft.unbara.ac.id
}

\begin{abstract}
Advances in developing technology, specific information technology, encourage people to develop media that can be used anytime and anywhere. In addition, classical learning methods require teachers to use media that are more relevant to the times, so students are more motivated to learn history. Media is a learning media that provides history for Interactive Media. Data collection techniques, tailored to the needs of the researchers themselves. Survey analysis is used to verify the data needed. The research objectives are: (a) making history of the development of interactive learning media Interactive Media for grade IX students of Odd Semester Middle School, (b) use media learning steps based on interactive learning media history for grade IX students in Odd Semester Middle School, (c) develop materials used in the development of history using Interactive Media for grade IX students of Odd Semester Middle School. As a result, history learning media can be applied well in Odd Semester Middle School.

Keywords: Learning Media, Interactive Media, E-Learning, Education, History
\end{abstract}

Intisari - Kemajuan teknologi yang berkembang, teknologi informasi khusus, mendorong orang untuk mengembangkan media yang dapat digunakan kapan saja dan di mana saja. Selain itu, metode pembelajaran klasik memerlukan guru untuk menggunakan media yang lebih relevan dengan zaman, sehingga siswa lebih termotivasi untuk belajar sejarah. Media adalah media pembelajaran yang memberikan sejarah bagi Media Interaktif. Teknik mengumpulkan data, disesuaikan dengan kebutuhan para peneliti itu sendiri. Analisis survei digunakan untuk memverifikasi data yang diperlukan. Tujuan penelitian adalah: (a) membuat sejarah pengembangan media pembelajaran interaktif Media Interaktif untuk siswa kelas IX SMP Semester Ganjil, (b) menggunakan langkahlangkah pembelajaran berbasis media pembelajaran interaktif sejarah media untuk siswa kelas IX di SMP Semester Ganjil, (c) mengembangkan bahan yang digunakan dalam pengembangan sejarah menggunakan Media Interaktif untuk siswa kelas IX SMP Semester Ganjil. Hasilnya media pembelajaran sejarah bisa diterapkan dengan baik pada Sekolah Menengah Pertama Semester Ganjil.

Kata kunci : Media Pembelajaran, Media Interaktif, ELearning, Pendidikan, Sejarah.

\section{PENDAHULUAN}

Dampak positif yang terjadi akibat perkembangan ilmu pengetahuan dan teknologi sekarang sangat terasa dalam dunia pendidikan. Sejalan dengan hal itu pemerintah berusaha untuk meningkatkan mutu. Pendidikan dengan mengadakan peningkatan kompetensi guru dan perbaikan kurikulum sesuai dengan kemajuan zaman, meningkatkan kualitas para pendidik dan menyediakan media-media pendidikan mulai dari yang sederhana sampai yang paling kompleks. Hal ini di maksudkan agar output pendidikan menjadikan manusia yang berkompeten yaitu manusia yang memiliki daya saing ilmu pengetahuan dan teknologi.

Untuk langkah awal dalam mengantisipasinya guru harus mempunyai kemampuan dalam memanfaatkan perkembangan teknologi dalam pembelajaran. Sehubungan dengan perkembangan teknologi dalam bidang pendidikan, sewajarnya penggunaan media belajar yang lebih beragam dipergunakan terutama pada bahan dan alat [1]. Bahan ajar ini digunakan sebagai pedoman siswa untuk meningkatkan wawasan mereka dalam memperdalam ilmu pengetahuan.

Mata pelajaran sejarah merupakan bagian dari ilmu pengetahuan sosial yang membahas mengenai perubahan aspek cerita kehidupan manusia di masa lampau yang lebih banyak mengingat hafalan tokoh atau nama pahlawan, tanggal, tahun dan tempat terjadinya peristiwa. Materi sejarah yang berisikan fakta-fakta, konsep-konsep harus mampu melatih daya nalar peserta didik dalam mengembangkan kemampuan berpikir. Dalam proses pembelajaran sejarah bagi peserta didik dengan menggunakan ranah kognitif menjadi sangat sulit, karena pada ranah ini perlu adanya suatu pengolahan informasi yang diserap pada setiap materi pembelajaran [2]. 


\section{Tinjauan Pustaka}

Latar belakang dari penelitian [2] adalah masih rendahnya kemampuan mengolah informasi siswa dalam pembelajaran sejarah di kelas XI IPS I SMA Pasundan 8 Bandung. Hal ini terlihat dari banyaknya siswa yang hanya mampu mengembangkan kemampuan mengingat dan mengafal. Ketika dihadapkan pada suatu persoalan, siswa belum mampu dalam mengolah informasi. Kemampuan mengolah informasi yang ditekankan pada penelitian ini adalah kemampuan siswa dalam mengolah informasi dari berbagai sumber informasi saat pembelajaran berlangsung. Untuk itu, peneliti mencoba melakukan penelitian dengan tujuan meningkatkan kemampuan mengolah informasi siswa melalui penerapan media film dalam pembelajaran sejarah. Adapun metode penelitian yang digunakan adalah metode penelitian tindakan kelas dengan menggunakan desain penelitian dari Kemmis dan Mc. Taggart. Metode penelitian tindakan kelas (PTK) dilakukan dengan empat tahap yaitu perencanaan (plan), tindakan (act), pengamatan (observing), dan refleksi (reflecting). Berdasarkan penelitian yang telah dilakukan, perkembangan siswa dalam mencapai kriteria pada indikator kemampuan mengolah informasi yang telah ditentukan mengalami peningkatan yang cukup signifikan pada setiap siklusnya. Melalui penerapan media film siswa terbiasa untuk mengolah informasi yang mereka peroleh. Hal ini menunjukkan bahwa dalam penerapan media film untuk meningkatkan kemampuan mengolah informasi siswa merupakan salah satu cara yang dapat digunakan dalam pembelajaran sejarah di sekolah. Hasil penelitian ini dapat dijadikan saran atau rekomendasi serta bahan pertimbangan untuk guru agar siswa memiliki kemampuan mengolah informasi sehingga pembelajaran sejarah lebih bermakna.

Perkembangan ilmu pengetahuan dan teknologi semakin mendorong upaya-upaya pembaharuan dalam pemanfaatan hasil teknologi dalam proses belajar. Para guru dituntut agar mampu menggunakan alat-alat yang sesuai dengan perkembangan dan tuntutan zaman. Guru juga dituntut untuk mengembangkan keterampilan untuk membuat media pembelajaran yang digunakannya. Dalam kurikulum 2013 pembelajaran di kelas menggunakan pendekatan scientific. Untuk itu guru harus memiliki pengetahuan dan pemahaman yang cukup untuk membuat media pembelajaran yang sesuai dengan pendekatan scientifik. media adalah bagian yang tidak terpisahkan dari proses pembelajaran demi tercapainya tujuan pendidikan pada umumnya dan tujuan pembelajaran sejarah pada khususnya.[1]

Pembelajaran dan komunikasi berbasis teknologi informasi adalah kebutuhan utama siswa di era Revolusi Industri 4.0. Kemudian, untuk menghadapi masyarakat 5.0, penggunaan media pembelajaran berbasis TIK adalah penting. Tujuan dari penelitian ini adalah untuk mengetahui efektivitas media Prezi pada kelas XI dalam pembelajaran sejarah. Subjek penelitian jenis ini adalah penelitian eksperimen dengan rumus one group pretestposttest design. Teknik pengumpulan data yang digunakan adalah observasi, kuesioner, wawancara dan tes. Efektivitas produk dapat dilihat dari skor gain. Hasil efektivitas pemanfaatan Prezi dalam kelompok kecil adalah $0,6 \%$ berarti dengan kualifikasi sedang dan kelompok besar $0,73 \%$ berarti dengan kualifikasi tinggi. Berdasarkan hasil yang diperoleh, media Prezi dapat digunakan sebagai media pembelajaran di sekolah untuk siswa [3].

Penelitian ini bertujuan untuk menghasilkan sejarah pembelajaran berbasis media melalui penggunaan situs web untuk Siswa Kelas XII di TKJ 2 SMK Negeri 1 Banawa Kabupaten Donggala. Media yang dikembangkan terdiri dari dua komponen, seperti: materi dan media pembelajaran. Pengembangan dilakukan melalui model berg dan model Gall. Media yang dikembangkan divalidasi oleh pakar materi dan pakar media. Hasil validasi mengungkapkan bahwa media berada dalam kategori sangat baik. Oleh karena itu, dapat disimpulkan bahwa pengembangan sejarah pembelajaran berbasis media melalui penggunaan situs web adalah tepat untuk meningkatkan pemahaman konsep dalam proses pembelajaran [4]. 
Penelitian eksploratif ini bertujuan untuk: 1) mengetahui tujuan, materi, metode, media, dan evaluasi pembelajaran Sejarah di Sekolah Menengah Atas (SMA); 2) mengidentifikasi faktor-faktor pendukung dan penghambat pembelajaran Sejarah di SMA; 3) mengeksploitasi pemahaman guru-guru Sejarah di SMA terhadap model-model pembelajaran Sejarah; dan 4) menyusun model Pembelajaran Sejarah Berbasis Pendidikan Karakter. Subjek penelitian adalah guru-guru Sejarah SMA Solo Raya. Teknik pengumpulan data yang digunakan adalah observasi, wawancara, analisis dokumen, angket dan Focus Group Discussion. Metode analisis data menggunakan analisis kualitatif model interaktif. Hasil penelitian menunjukkan, bahwa: 1) tujuan pembelajaran Sejarah menanamkan semangat kebangsaan cinta bangsa dan tanah air; materi sesuai dengan Standar Isi; metode ceramah bervariasi, media power point, film dan Liquid Crystal Display, sedangkan evaluasinya masih banyak pada aspek kognitif; 2) Faktor pendukung pembelajaran Sejarah, yaitu adanya model-model pembelajaran inovatif, faktor penghambatnya buku BSE yang minim, dan adanya diskriminatif mata pelajaran; 3) sebagian besar guru-guru SMA telah memahami modelmodel pembelajaran; dan 4) tersusunnya model Kritis, Kreatif, Berantai dan Berkarakter (KKBB) [5].

Penelitian [6] bertujuan untuk mengetahui media pembelajaran yang digunakan guru, kendala- kendala yang dialami guru dalam penggunaan media, dan solusi untuk mengatasi kendala-kendala yang dialami guru dalam penggunaan media pembelajaran.penelitian mengambil lokasi di SMA Kabupaten Semarang dengan menggunakan metode wawancara, observasi, dan studi dokumentasi. Hasil penelitian menunjukkan bahwa media yang digunakan diantaranya LCD, peta, globe, film dokumenter, CD pembelajaran, gambar-gambar tokoh, buku, internet, dan lain sebagainya. Kendala yang dialami guru dalam penggunaan media pembelajaran sejarah yang menerapkan Kurikulum KTSP adalah guru kurang memaksimalkan media yang telah tersedia se- bagai fasilitas sekolah, dan kreatifitas guru dalam inovasi media pembelajaran yang kurang, se- dangkan kendala yang ditemui guru dalam penggunaan media pembelajaran di sekolah yang men- erapkan Kurikulum 2013 tidak terlalu spesifik, hanya saja kendala itu bersifat kondisional saja.

Penelitian [7] bertujuan untuk mengetahui gambaran pengembangan blog mata kuliah Sejarah Kontemporer Eropa. Penelitian ini dilatarbelakangi oleh belum maksimalnya penggunaan blog pembelajran pada mata kuliah Sejarah Kontemporer Eropa dan blog yang sudah ada kurang menarik bagi mahasiswa sehingga tidak dapat meningkatkan antusiasme dalam segi penggunaannya. Metode penelitian yang digunakan pada penelitian ini adalah Metode Penelitian dan Pengembangan, yaitu metode penelitian yang digunakan untuk menghasilkan produk tertentu, dan menguji keefektifan produk tersebut. Berdasarkan angket penilai dari ahli media di atas bahwa hasil penilaian dari media pembelajran yang dibuat memiliki rata-rata nilainya $85,4 \%$ sehingga dikategorikan sangat layak untuk digunakan dalam proses pembelajaran dengan mengacu pada skala Likert. Hasil pengumpulan data tanggapan pemakaian terbatas ditinjau dari aspek tampilan media, penggunaan bahasa,penggunaan blog, dan manfaat blog diperoleh skor 337,75 \% dan rata-rata mencapai $84,43 \%$. Hasil tanggapan pemakaian lebih luas ditinjau dari aspek (1) Tampilan media, memperoleh skor 490 dengan persentase pencapaian 85,06\%, Penggunaan bahasa, memperoleh skor 432 dengan persentase pencapaian 84,25\%, (3) Penggunaan blog, memperoleh skor 500 dengan persentase pencapaian $86,80 \%$, dan (4) Manfaat blog, memperoleh skor 539 dengan presentase pencapaian 93,57\%. Berdasarkan tabel skala Likert, hasil dari masing-masing indikator pengembangan media pembelajaran blog yang sudah diujicobakan berada di ruang lingkup layak.

\section{Metodologi Penelitian}

Metode yang digunakan dalam pengembangan sistem meliputi studi literatur, analisis SWOT, perancangan, testing, dan pengujian sistem. Untuk Studi Kepustakaan seperti mempelajari buku-buku refrensi yang untuk membantu dalam pembuatan media pembelajaran sejarah kelas ix semester ganjil. Metode yang Menganalisa 
perangkat keras dan perangkat lunak serta analisis SWOT dan analisis kelayakan. Metode perancangan sistem mengikuti System Development Life Cycle. Dan pada tahap akhir metode testing menggunakan Metode Black Box Testing Serta White Box Testing.

\section{KESIMPULAN DAN SARAN}

\section{A. Sejarah Multimedia}

Istilah multimedia berawal dari teater, bukan computer. Pertunjukan yang memanfaatkan lebih dari satu medium seringkali disebut pertunjukan multimedia. Pertunjukan multimedia mencakup monitor video, synthesized band, dan karya seni manusia sebagai bagian dari pertunjukan. Sistem Multimedia dimulai pada akhir 1980-an dengan diperkenalkannya Hypercard oleh Apple pada tahun 1987, dan pengumuman oleh IBM pada tahun 1989 mengenai perangkat lunak Audio Visual Connection (AVC) dan video adaphter card bagi PS/2. Sejak permulaan tersebut, hampir setiap pemasok perangkat keras dan lunak melompat ke multimedia. Pada 1994, diperkirakan ada lebih dari 700 produk dan system multimedia dipasaran. Citra visual dapat dimasukan kedalam system dari paket perangkat lunak yang menyatukan digital, dan dari kamera video, pita dan piringan video, dan scanner optic. Input audio dapat dimasukan melalui mikrofon, pita kaset, dan compack disk.

\section{B. Penggunaan Multimedia}

Multimedia dapat digunakan dalam banyak bidang. Multimedia dapat masuk dan menjadi alat bantu yang menyenangkan. Hal ini terjadi karena kekayaan elemenelemen dan kemudahannya digunakan dalam banyak konten yang bervariasi. Beberapa bidang yang menggunakan multimedia adalah sebagai berikut :

1) Bisnis :

Aplikasi multidemia untuk bisnis meliputi presentasi, pemasaran, periklanan, demo produk, katalok, komunikasi di jaringan, dan pelatihan. Penggunaan multimedia akan membuat kelancaran kemudahan transaksi bisnis.

2) Sekolah
Multimedia sebenarnya sangat dibutuhkan disekolah karena multimedia membuat pembelajaran menjadi lebih lengkap dan lebih menarik. Multimedia dapat menjadi alat pembelajaran elektronik yang dapat membantu pengajar.

3) Rumah

Multimedia dapat dimanfaatkan sebagai media hiburan dan teman di rumah, misalnya game.

4) Tempat umum

Saat ini sudah banyak tempat-tempat umum memasang "kiosk", yaitu produk multimedia yang berfungsi sebagai pemberi informasi, misalnya informasi mengenai tempat yang sedang dikunjungi, kuliner, dan sebagainya.

5) Virtual Reality (VR)

Bidang ini biasanya menggunakan alat-alat khusus, misalnya kacamata, helm, sarung tangan, dan antarmuka pengguna yang tidak lazim, dan berusaha untuk menempatkan penggunaanya didalam pengalaman yang nyata. Dalam VR, lingkungan yang diciptakan sebenarnya merupakan ribuan objek geometris yang digambar dalam ruang 3 dimensi.

\section{Analisis dan interface sistem}

1) Analisis SWOT

Analisia ini didasarkan pada hubungan atau interaksi antara unsur-unsur internal, yaitu kekuata dankelemahan terhadap unsur-unsur eksternal yaitu peluang dan ancaman.

2) Analisis Kebutuhan

Analisis Kebutuhan adalah proses dalam apa saja yang akan dibutuhkan dalam pembuatan media pembelajaran ini. Kebutuhan Sistem terbagi menjadi dua kebutuhan yaitu :

3) Kebutuhan Fungsional

Kebutuhan Fungsional Dalam pembuatan media pembelajaran sejarah ini berisikan informasiinformasi mengenai materi seputar mata pelajaran sejarah semester ganjik kelas ix.

4) Kebutuhan Non Fungsional 
Kebuutuhan Non fungsional meliputi kebutuhan perangkat keras, kebutuhan perangkat lunak, dan kebutuhan sumber daya manusia.

5) Studi Kelayakan

Studi Kelayakan adalah suatu studi yang akan digunakan untuk menentukan media pembelajaran sejarah layak diteruskan atau dihentikan. faktor yang akan mempengaruhi kelayakan antara lain kelayakan teknologi, kelayakan hukum dan kelayakan Operasional.

6) Perancangan Media Pembelajaran

Perancangan memiliki dokumen yang mengimplementasikan seluruh ide dan konsep dari media pembelajaran yang akan dibuat. Rancangan isi media pembelajaran berisi rincian media pembelajaran yang meliputi rancangan flowchart, rancangan naskah media pembelajaran dan resource media pembelajaran yang lain beserta informasi lainnya.

7) Konsep Dasar Media Pembelajaran

Dalam pembuatan aplikasi berbasis multimedia ini, memadukan empat unsur penting multimedia, yaitu : teks, animation, audio, image. Dengan perpaduan keempat unsur tersebut aplikasi ini akan lebih menarik dan lebih bervariasi sehingga menimbulkan minat bagi siswa.

8) Perancangan Isi

Perancangan isi diperlukan untuk memberikan kemudahan dalam penyampaian informasi untuk para siswa melalui aplikasi media pembelajaran dengan membagi isi yang ada menjadi beberapa bagian yaitu : Halaman Home, Halaman Evaluasi, Halaman materi pelajaran sejarah.

9) Flowchart media pembelajaran

Flowchart adalah untuk menyederhanakan rangkaian proses. Untuk lebih jelas perhatikan gambar 1 .

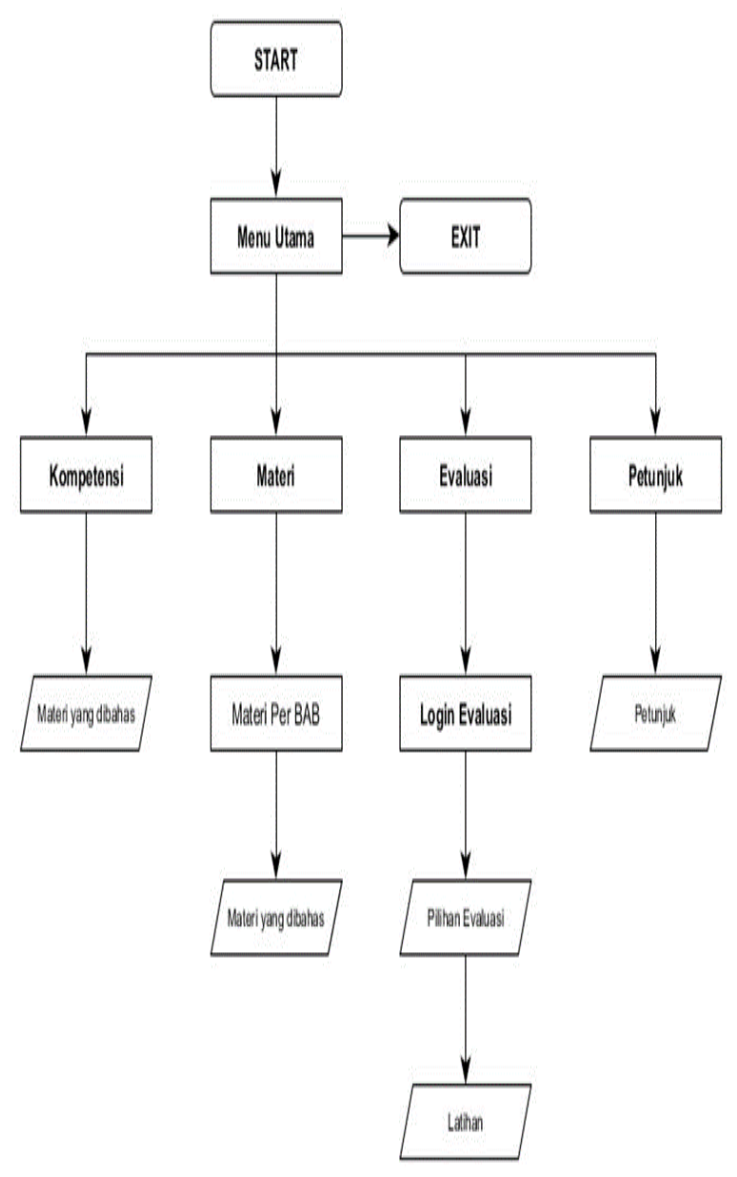

Gambar 1. Rancangan Flowchart Media Pembelajaran

\section{1) Rancangan Antar Muka}

Rancangan antar muka merupakan rancangan awal sebelum atau sketsa untuk membuat tampilan pada aplikasi tersebut. Adapun rancangan antar muka yang terdapat pada media pembelajaran sejarah kelas ix semester ganjil.

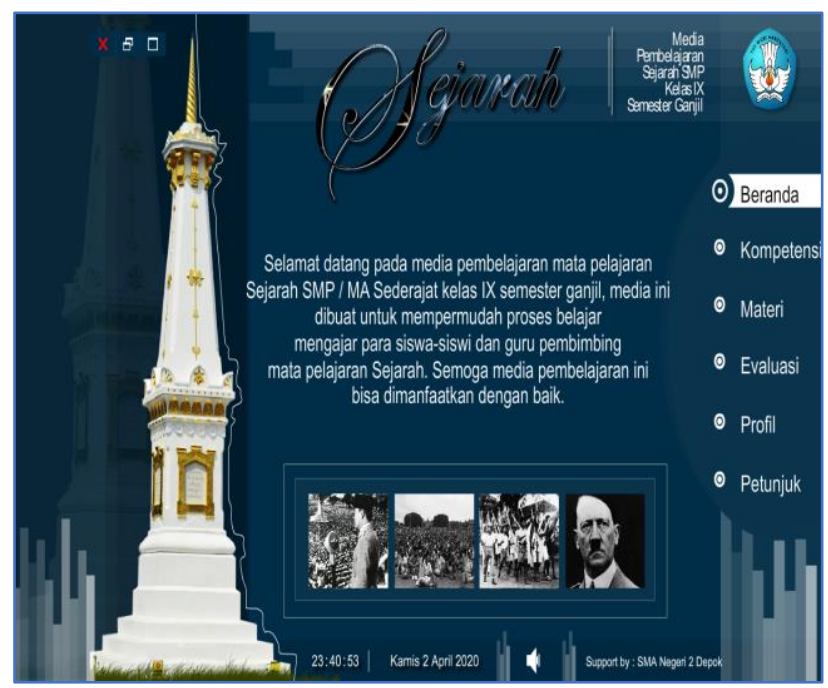

Gambar 2. Halaman Beranda 


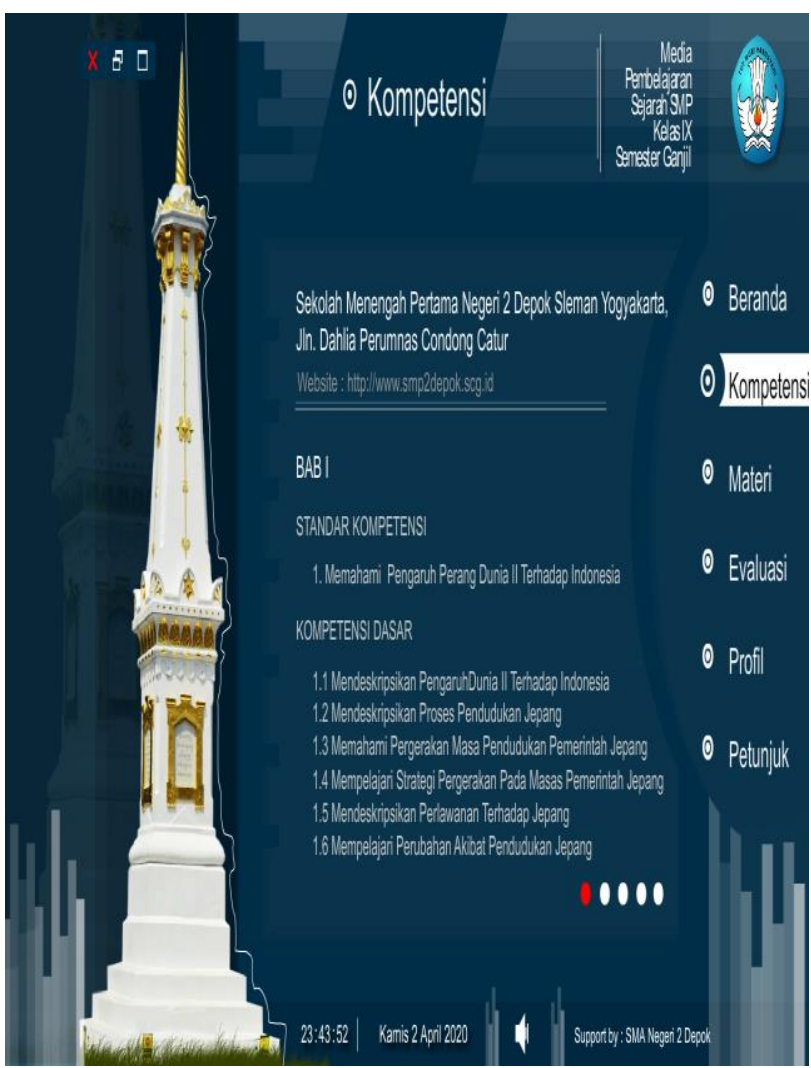

Gambar 3. Halaman Kompetensi.

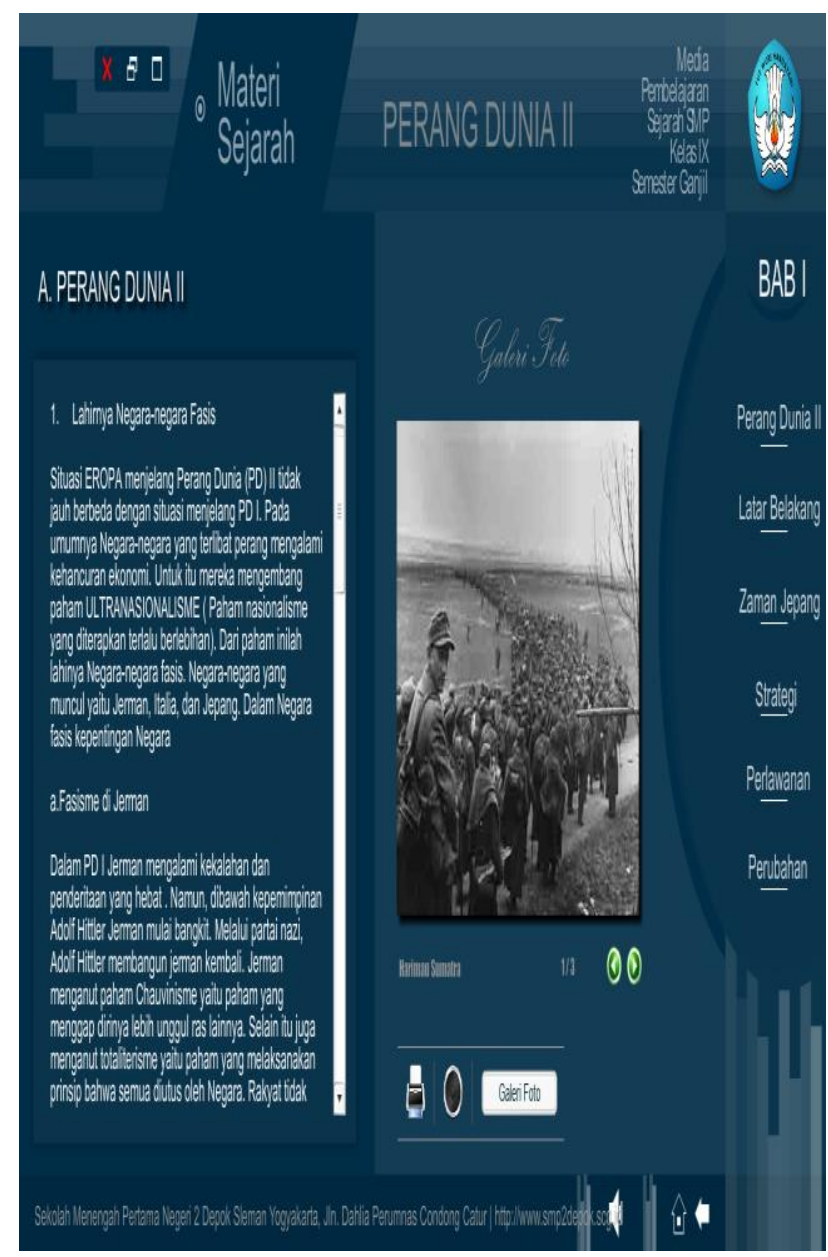

Gambar 4. Halaman Materi

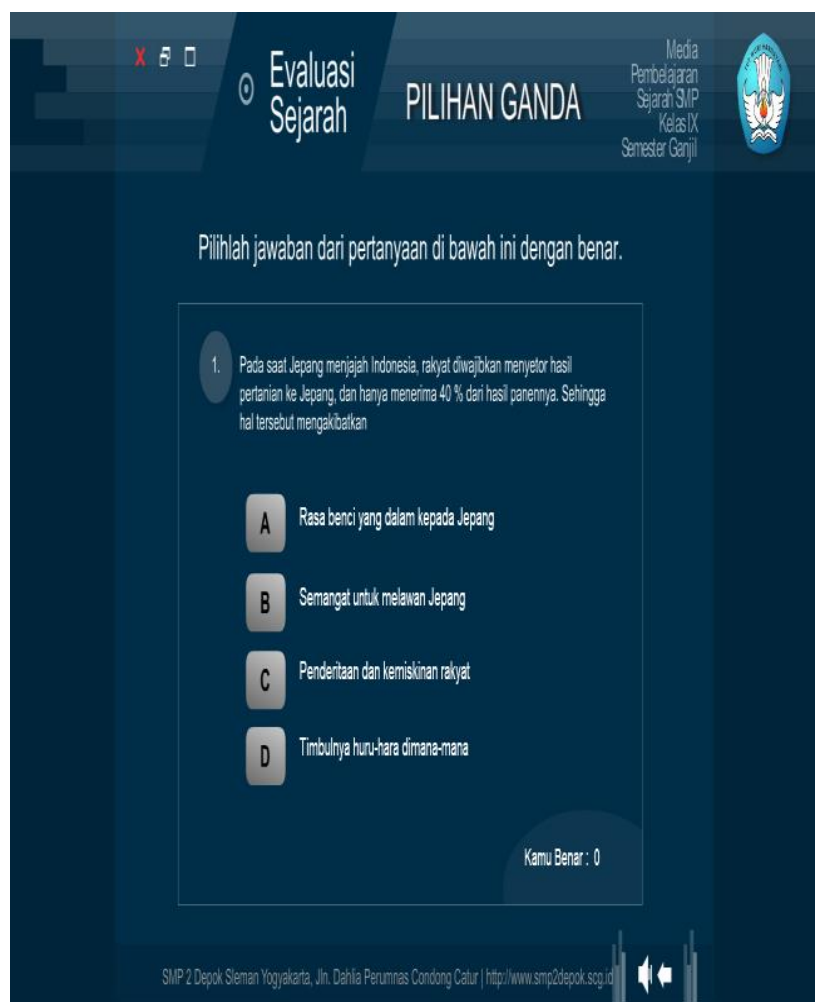

Gambar 5. Halaman Evaluasi

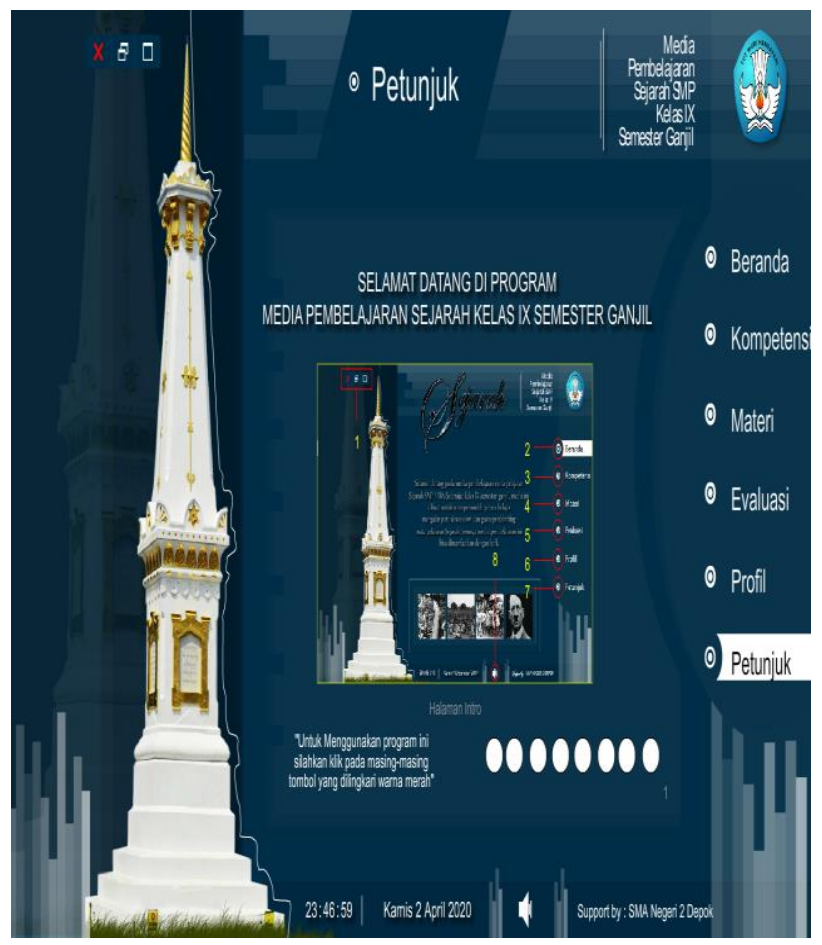

Gambar 6. Halaman Petunjuk

\section{Implementasi Dan Pembahasan}

1. Implementasi Pembuatan Media

Implementasi adalah sebuah tahap dimana untuk penerapan dari sistem yang dibuat. Tujuan dari implementasi adalah untuk pengujian sistem apakah 
aplikasi tersebut berjalan lancar atau tidak sebelum diimplementasikan di masyarakat berikut adalah sistematika dari implementasi : a) Persiapan bahanbahan media. Pembuatan, (pembuatan bahan, pembuatan file awal pada flash, memasukan bahanke library flash, pembuatan movie clip dan button dan pembuatan animasi pada flash). B) Pembuatan Dan Listing Program Pembuatan media pembelajaran sejarah ini meliputi tampilan interface dan media screen.

\section{Listing Program}

Dalam pembuatan media pembelajaran ini terdapat beberapa script flash (Script didalam frame, script pemanggilan data, script pada tombol dan script pada kuis) yang berguna dalam tombol maupun pada frame flash.

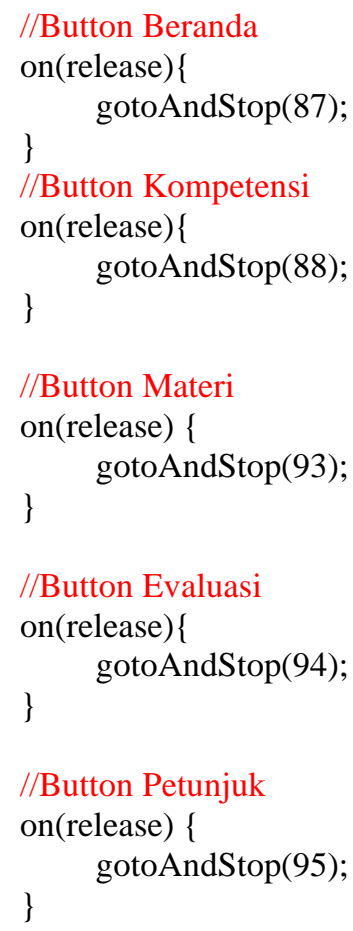

3. Exporting Aplikasi Flash

Proses exporting ialah kegiatan akhir dalam membuat dalam satu file yang utuh, hal ini dilakukan untuk memudahkan pengguna dalam menggunakan aplikasi ini.

a. Pemeliharaan Media Pembelajaran

Pemeliharaan aplikasi perlu dilakukan agar sistem dapat berjalan lebih baik dan bertahan lebih lama baik dilakukan dengan penjagaan dari aset media itu sendiri ataupun komponennya.

b. Pengujian Metode Black Box dan White Box Testing

Black Box Testing merupakan sebuah metode yang digunakan untuk menemukan kesalahan dan mendemonstrasikan fungsional aplikasi saat dioperasikan, apakah input diterima dengan benar dan output yang dihasilkan telah sesuai dengan yang diharapkan White box adalah perancangan test case yang menggunakan struktur control dari perancangan procedural untuk mendapatkan test case.

\section{KESIMPULAN}

Dari uraian dan pembahasan pada media pembelajaran Sejarah Kelas IX Semester Ganjil maka dapat ditarik kesimpulan sebagai berikut :

1. Untuk membuat aplikasi Media Pembelajaran sejarah diperlukan tahapan-tahapan untuk menyelesaikannya, dimana pengumpulan data dilakukan langsung menemui guru terkait agar materi yang disampaikan bisa maksimal.

2. Media pembelajaran sejarah ini dalam proses input data materi dan sata evaluasi bisa dilakukan pada file .xml dengan memilih per sub bab yang ingin dimasukan.

3. Media pembelajaran kelas IX SMP semester ganjil ini telah diuji dan telah dinyatakan lulus uji validasi.

\section{DAFTAR PUSTAKA}

[1] Y. Rahelly, "Media Pembelajaran Sejarah Dalam Kurikulum 2013,” J. CRIKSETRA, vol. 4, pp. 92-98, 2015 .

[2] L. S. Widiani, W. Darmawan, and T. Ma`mur, "Penerapan Media Film Sebagai Sumber Belajar Untuk Meningkatkan Kemampuan Mengolah Informasi Siswa Dalam Pembelajaran Sejarah," J. Sej. DAN Pendidik. Sej., vol. 7, no. 1, pp. 123-132, 2018.

[3] S. Elisva, U. Nurul, and Sumardi, "The Effectiveness Of Prezi Media For History Learning 
Of The Eleventh Grade," J. Hist., vol. 3, no. 2252, pp. 1-11, 2019.

[4] Risma, Juraid, and Suyuti, "Pengembangan Media Pembelajaran Sejarah Melalui Pemanfaatan Website Pada Kelas XII TKJ 2 SMK Negeri 1 Banawa Kabupaten Donggala," e J. Katalogis, vol. 4, pp. 1-9, 2016.

[5] L. A. S, "Pengembangan Model Pembelajaran Sejarah SMA Berbasis Pendidikan Karakter Di Solo Raya," J. Pendidik. dan Kebud., vol. 18, pp. 412426, 2012.

[6] H. Alionita, "Penggunaan Media Dalam Pembelajaran Sejarah Sma Di Kabupaten Semarang," Indones. J. Hist. Educ., vol. 3, no. 2, pp. 31-35, 2014.

[7] O. A. K. Shavab and Gurdjita, "Pengembangan Media Pembelajaran Blog Pada Mata Kuliah Sejarah Kontemporer Eropa," J. Candrasangkala, vol. 3, no. 2, pp. 20-26, 2017. 